\title{
Determinants of Complete Infant Immunization and Contextual Effect of Community Health Centers: A Multilevel Evidence from Karanganyar, Central Java
}

\author{
Maharani Ulfah"), Supriyadi Hari Respati²), Bhisma Murti1) \\ 1)Masters Program of Public Health, Universitas Sebelas Maret \\ 2)Faculty of Medicine, Universitas Sebelas Maret
}

\section{ABSTRACT}

Background: Immunization aims to reduce morbidity, mortality, and disability due to vaccine-preventable diseases. Many children in Indonesia have not received any immunization, or their immunization status is incomplete. Efforts should be made to raise awareness of parents to participate in completing their child's immunization. This study aimed to analyze the behavioral factors that influence the completeness of immunization in infants

Subjects and Method: A cross-sectional study conducted at 21 health centers in Karanganyar, Central Java, from January to March 2020. Subjects were 200 mothers with children aged 12-23 months that were selected using a fixed disease sampling technique. The dependent variable was the completeness of immunization. The independent variables at level 1 were education, knowledge, information and education, perceived benefits, perceived barriers, intentions, subjective norms, and attitudes. The independent variables at level 2 were the contextual health center. The data were collected by questionnaire and analyzed using a multilevel analysis.

Results: Complete immunization in infants probably occurred with high maternal education $(\mathrm{OR}=24.02 ; 95 \% \mathrm{CI}=1.61$ to $359.17 ; \mathrm{p}=0.021)$, information obtained $(\mathrm{OR}=52.31 ; 95 \% \mathrm{CI}=1.35$ to 2021.69; $\mathrm{p}=0.034)$, good knowledge (OR = $49.20 ; 95 \% \mathrm{CI}=71.54$ to $1574.62 ; \mathrm{p}=0.028)$, high perceived benefit $(\mathrm{OR}=31.26 ; 95 \% \mathrm{CI}=1.28$ to $762.77 ; \mathrm{p}=0.035)$, strong intention ( $\mathrm{OR}=$ $17.84 ; 95 \% \mathrm{CI}=1.59$ to $199.83 ; \mathrm{p}=0.019)$, supportive subjective norm $(\mathrm{OR}=94.69 ; 95 \% \mathrm{CI}=$ 1.91 to $4683.14 ; \mathrm{p}=0.022)$, positive attitude $(\mathrm{OR}=68.71 ; 95 \% \mathrm{CI}=2.40$ to $1967.08 ; \mathrm{p}=0.013)$. Completeness of immunization in infants decreased with big perceived barrier $(\mathrm{OR}=0.02 ; 95 \%$ $\mathrm{CI}=0.01$ to $0.67 ; \mathrm{p}=0.028)$. Health center accreditation showed a contextual effect on the level of completeness of immunization with Intra-Class Correlation $(\mathrm{ICC})=\mathbf{2 0 . 4 2 \%}$.

Conclusion: Immunization completeness in infants increases with high maternal education, good knowledge, high perceived benefits, strong intentions, supportive subjective norms, positive attitudes. Completeness of immunization decreased with a big perceived barrier. Health centers have a large contextual influence on the completeness of immunization in infants.

Keywords: immunization completeness, health center context, multilevel analysis

\section{Correspondence:}

Maharani Ulfah. Masters Program in Public Health, Universitas Sebelas Maret. Jl. Ir. Sutami 36A, Surakarta 57126, Central Java. Email: maharaniulfahh@gmail.com. Mobile: +628213558003557.

Cite this as:

Ulfah M, Respati SH, Murti B (2020). Determinants of Complete Infant Immunization and Contextual Effect of Community Health Centers: A Multilevel Evidence from Karanganyar, Central Java. J Matern Child Health. 05(05): 456-466. https://doi.org/10.26911/thejmch.2020.05.05.01.

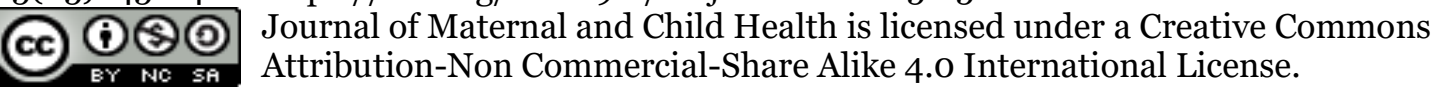

\section{BACKGROUND}

Sustainable development goals across countries are spelled out internationally in Sustainable Development Goals (SDGs).
Sustainable development starts with children. A healthy and prosperous life is the third goal of sustainable development related to children. Priority targets for children include; 
1) ending deaths in infants and children under five years of age from preventable causes; 2) ending the epidemics of AIDS, tuberculosis (TB), malaria, hepatitis, and other infectious diseases; 3) achieve universal health coverage, including access to medicines and basic vaccines that are safe, effective, quality, and affordable for all (Ministry of National Development Planning of the Republic of Indonesia/National Development Planning Agency and UNICEF, 2017).

According to WHO, about 1.5 million children die each year because of diseases that can be prevented by immunization. Low immunization coverage is an indicator of death due to vaccine-preventable diseases or PD3I (Ministry of Health RI, 2019).

The immunization program is expected to reduce or prevent disease, especially infectious diseases that have shown results. According to the former Minister of Health of the Republic of Indonesia, vaccination does not protect $100 \%$, but it reduces the risk of infection and reduces the impact of infection occurs (Sunarti, 2012). Studies have also shown that successful immunization efforts against infectious diseases have saved lives more than other health programs, except for the provision of clean water (IDAI, 2014).

Data from the Directorate of Disease Prevention and Control, Ministry of Health of the Republic of Indonesia shows that since 2014-2016, accounting for around 1.7 million children in Indonesia have not received immunizations or their immunization status is incomplete (Ministry of Health of Republic of Indonesia, 2018). Complete basic immunization coverage (IDL) reaches $86.8 \%$ and needs to be increased to reach the target of $93 \%$ by 2019. Village Universal Child Immunization (UCI) in 2015 reached $82.9 \%$ and needs to be increased to reach $92 \%$ in 2019 (Ministry of Health of Republic of Indonesia, 2015).
Health data for Karanganyar Regency in 2018 shows that there are two sub-districts that have UCI far from the 2019 national target (92\%) (Health Office of Karanganyar Regency, 2018). The results of a preliminary study in the District showed that there were 146 cases of rejection of basic immunization (infants and under-five) from a total target of 12,169 babies in 2018. Meanwhile, in mid2019, starting from January to June 2019, there were 117 cases of refusal of basic immunization.

Health centers are expected to be competent, innovative health service institutions that lead to patient needs and satisfaction, especially (Kholifah et al., 2019). Information and education about immunization in infants must be provided by health workers at the Puskesmas to the community. Education about immunization is given to motivate mothers to immunize their children so that UCI coverage in Indonesia can reach 100\%.

Several previous studies have shown that individual factors, community environmental factors, socio-economic factors, and parents' perspectives on vaccines influence the success of immunization. This is in accordance with the biopsychosocial health model, where biological, psychological, and spiritual aspects make a major contribution to a person's health status (Ntenda et al., 2017; Oleribe et al., 2017; Papadimitriou et al., 2017).

Factors that affect the status of immunization completeness can also be analyzed using behavioral theories, including the Health Belief Model (HBM) and Theory of Planned Behavior (TPB). HBM refers to a person's assumptions about understanding changed behavior. Meanwhile, TPB explained that behavior change starts with prior intention. 
Ulfah et al./ Determinants of Complete Infant Immunization

\section{SUBJECTS AND METHOD}

\section{Study Design}

This type of study was analytic observational with the cross-sectional approach. The study period was from January to March 2020. The study sites were 21 health centers in Karanganyar, Central Java.

\section{Population and Sample}

The study population was 200 children aged 12-23 months in Karanganyar, Central Java. This study used stratified random sampling at the community level, fixed disease sampling at the individual level.

\section{Study Variables}

The dependent variable was immunization completeness. The independent were maternal education, knowledge, information, perceived benefits, perceived barriers, intentions, subjective norms, attitudes, and contextual health centers.

\section{Operational Definition of Variables} Education was the mother's formal education level. This formal education includes the levels of elementary school, junior high school, senior high school/equivalent, and higher education. The measuring instrument used was a questionnaire. The data scale used was a dichotomy. Code $\mathrm{O}=$ low $(<$ Senior High School / equivalent); and $1=$ height ( $\geq$ Senior High School/equivalent).

Knowledge was everything a mother knows about immunization and dangerous infectious diseases. The knowledge included the purposes, benefits, and methods of vaccine administration as well as some knowledge about disease transmission and its fatal rate. The measuring instrument used was a questionnaire. The data scale used was continous, and to facilitate analysis, the data was transformed into a dichotomy. Code $\mathrm{O}=$ less $(<7.02)$; and $1=\operatorname{good}(\geq 7.02)$.

Information was an explanation received by mothers from health workers about basic immunization programs in infants. The measuring instrument used was a question- naire. The data scale used was a dichotomy. Code $\mathbf{0}=$ never received information; and $\mathbf{1}=$ have received information.

The perceived benefits was the mother's assessment of the benefits of immunization. The measuring instrument used was a questionnaire. The data scale used was continous, and to facilitate analysis, the data was transformed into a dichotomy. Code $\mathrm{O}=$ low $(<7.25)$; and $1=\operatorname{high}(\geq 7.25)$.

Perceived barriers were obstacles felt by mothers in immunization, including aspects of family support, distance, time, security, and the effects of immunization. The measuring instrument used was a questionnaire. The data scale used was continuous, and to facilitate analysis, the data was converted into a dichotomy. Code $\mathrm{o}=$ small $(<9.77)$; and 1 = large $(\geq 9.77)$.

The intention was the mother's conscious plan and readiness to immunize her child. The measuring instrument used was a questionnaire. The data scale used was continous, and to facilitate analysis, the data was transformed into a dichotomy. Code $\mathrm{O}=$ weak $(<4.52)$; and $1=$ strong $(\geq 4.52)$.

Subjective norms were the mother's opinion about the immunization rules or standards in her environment. The measuring instrument used was a questionnaire. The data scale used was continuous, and to facilitate analysis, the data was converted into a dichotomy. Code $\mathrm{O}=$ not supported $(<5.76)$; and $1=$ support $(\geq 5.76)$.

Attitude was the response and assessment of the mother to the immunization program for babies. The measuring instrument used was a questionnaire. The data scale used was continuous, and to facilitate analysis, the data was converted into a dichotomy. Code $\mathrm{O}=$ negative $(<7.73)$; and $1=$ positive $(\geq 7.73)$.

\section{Study Instruments}

The measuring instrument used was a questionnaire. 


\section{Data Analysis}

Univariate analysis was used to describe each dependent and independent variable. The data were then grouped according to the type of data and entered into a frequency distribution table. Bivariate analysis was used to determine the correlation between the independent variable and the dependent variable using the Chi-square test.

The multivariate analysis could explain the effect of the independent variable on the dependent variable using multilevel analysis.

\section{Research Ethic}

This study was based on research ethics, namely the approval of the research, anony- mity, confidentiality, and the feasibility of ethics. Ethical permission in this study was obtained from the Ethics Commission of Dr. Moewar in Surakarta, Indonesia, No. 113/I/ HREC/2020.

\section{RESULTS}

\section{Sample Characteristics}

This study was conducted based on research ethics, namely, research approval, anonymity, confidentiality, and ethical feasibility. Ethical permission in this research was obtained from the Ethics Commission of Dr. Moewardi, Surakarta, Indonesia, No. 113 / I / HREC / 2020.

Table 1. Description of the characteristics of the continuous data sample

\begin{tabular}{lccccc}
\hline Variable & N & Mean & SD & Min. & Max. \\
\hline Knowledge & 200 & 7.02 & 2.05 & 2 & 10 \\
Perceived benefits & 200 & 7.25 & 2.35 & 3 & 10 \\
Perceived barriers & 200 & 9.77 & 3.32 & 0 & 14 \\
Intention & 200 & 4.52 & 1.47 & 0 & 6 \\
Subjective norms & 200 & 5.76 & 2.22 & 0 & 8 \\
Attitude & 200 & 7.73 & 2.13 & 4 & 10 \\
\hline
\end{tabular}

\section{Univariate analysis}

Table 2 shows a description of the results of each of the variables studied. The percentage of study subjects whose immunization status was complete 50 subjects (25\%) and whose immunization status was incomplete was 150 subjects (75\%). This showed that the immunization coverage had not reached the target of $100 \%$. The results showed that the information variable had a big difference between the subjects who did not get information and the subjects who got information. A total of 132 study subjects (66.0\%) did not get information, and only 68 study subjects (34.0\%) received information. In the attitude variable, which was divided into positive attitudes and negative attitudes, the result was 126 subjects (63\%) had positive attitudes and 74 subjects (37\%) had negative attitudes. This showed that most of the subjects had an attitude that accepts and supports the immunization program.

\section{The result of bivariate analysis}

There was an effect of education knowledge, information, perceived benefit, perceived barriers, intentions, subjective norms, and attitudes on immunization completeness, and it was statistically significant. Mothers with higher education were 10.19 times more likely to fully immunize their children compared to those with low education $(\mathrm{OR}=10.19$; $\mathrm{p}<$ o.001). Mothers who received information about immunization were 11.98 times more likely to immunize their children than those who did not $(\mathrm{OR}=11.98 ; \mathrm{p}<0.001)$. Mothers with good knowledge were 18.25 times more likely to fully immunize their children than those with less knowledge $(\mathrm{OR}=18.25$; $\mathrm{p}$ $<0.001)$. Mothers with high perceived benefits were 17.74 times more likely to fully immunize their children compared to those with low perceived benefits $(\mathrm{OR}=17.74$; $<0.001)$. 
Table 2. Description of the characteristics of the categorical data sample

\begin{tabular}{lcc}
\hline Variable & n & \% \\
\hline Immunization completeness & 150 & 75.0 \\
Complete & 50 & 25.0 \\
Incomplete & & \\
Education & 107 & 53.5 \\
Low $(<3)$ & 93 & 46.5 \\
High ( $\geq 3)$ & & \\
Information & 68 & 34.0 \\
Received information $(<3)$ & 132 & 66.0 \\
Received no information $(\geq 3)$ & & 56.5 \\
Knowledge & 113 & 43.5 \\
Poor $(<3)$ & 87 & 47.5 \\
Good $(\geq 3)$ & & 52.5 \\
Perceived benefits & 95 & 46.5 \\
Low $(<3)$ & 105 & 53.5 \\
High $(\geq 3)$ & & \\
Perceived barriers & 93 & 41.5 \\
Small $(<3)$ & 107 & 58.5 \\
Big $(\geq 3)$ & & \\
Intention & 83 & 41.0 \\
Weak $(<3)$ & 117 & 59.0 \\
Strong $(\geq 3)$ & & \\
Subjective norms & 82 & 63.0 \\
Support $(<3)$ & 118 & \\
Not support $(\geq 3)$ & & 74 \\
Attitude & 126 & \\
Negative $(<3)$ & & \\
Positive $(\geq 3)$ & & \\
\hline
\end{tabular}

Mothers with a high perceived barrier had 0.24 times the possibility of completely immunizing their children compared to those with low perceived barriers $(\mathrm{OR}=0.24$; $\mathrm{p}<0.001)$. Mothers with strong intentions were $\mathbf{1 7 . 9 1}$ times more likely to completely immunize their children compared to those with weak intentions $(\mathrm{OR}=17.91 ; \mathrm{p}<0.001)$. Mothers with supportive subjective norms were more likely to immunize their children 12.46 times than unsupportive subjective norm completely $(\mathrm{OR}=12.46 ; \mathrm{p}<0.001)$. Mothers with positive attitudes were 10.06 times more likely to immunize their children completely compared to mothers with negative attitudes $(\mathrm{OR}=10.06 ; \mathrm{p}<0.001)$.

\section{The result of multilevel analysis}

Multilevel logistic regression analysis explained the effect of more than one independent variable, namely education, knowledge, information, perceived benefits, perceived barriers, intention, subjective norms, attitudes toward the dependent variable, namely the completeness of immunization in infants.

Table 4 shows a significant influence between education, information, knowledge, perceived benefits, perceived barriers, intention, subjective norms, and attitudes towards completeness of immunization.

Mothers with high education were 24.02 times more likely to immunize their children than those with low education $(\mathrm{OR}=$ 24.02; $95 \% \mathrm{CI}=1.61$ to $359.17 ; \mathrm{p}=0.021$ ). Mothers who received information were 52.31 times more likely to fully immunize their children than those without information $(\mathrm{OR}=52.31 ; 95 \% \mathrm{CI}=1.35$ to $2021.69 ; \mathrm{p}=$ 
0.034). Mothers with good knowledge were 49.20 times more likely to fully immunize their children than those with less knowledge $(\mathrm{OR}=49.20 ; 95 \% \mathrm{CI}=71.54$ to $1574.62 ; \mathrm{p}==$ o.028). Mothers with high perceived benefits were 31.26 times more likely to completely immunize their children compared to those with low perceived benefits $(\mathrm{OR}=31.26 ; 95 \%$ $\mathrm{CI}=1.28$ to $762.77 ; \mathrm{p}=0.035)$. Mothers with high perceived barriers were more likely to completely immunize their children with 0.02 compared to those with low perceived barriers $(\mathrm{OR}=0.02 ; 95 \% \mathrm{CI}=0.01$ to $0.67 ; \mathrm{p}=$ 0.028). Mothers with strong intention were 17.84 times more likely to immunize their children than those with weak intention (OR 17.84; 95\% CI $=1.59$ to 199.83 ; $\mathrm{p}=0.019$ ).
Mothers with supportive subjective norms were more likely to immunize their children completely 94.69 times compared with unsupportive subjective norms $(\mathrm{OR}=94.69$; $95 \% \mathrm{CI}=1.91$ to $4683.14 ; \mathrm{p}=0.022)$. Mothers with positive attitudes were 68.71 times more likely to immunize their children than those with negative attitudes $(\mathrm{OR}=68.71 ; 95 \% \mathrm{CI}=$ 2.40 to $1967.08 ; \mathrm{p}=0.013$ ).

The Health center had a contextual influence with an ICC of $20.42 \%$. This means that factors at the health center level influenced $20.42 \%$ of the variation in immunization completeness. This figure was greater than the standard rule of thumb 8$10 \%$ so that the contextual influence of the health centers cannot be ignored.

Table 3. shows the results of the bivariate analysis using the chi-square test.

\begin{tabular}{|c|c|c|c|c|c|c|}
\hline \multirow{3}{*}{ Independent Variable } & \multicolumn{4}{|c|}{ Immunization Completeness } & \multirow{3}{*}{$\mathbf{O R}$} & \multirow{3}{*}{$\mathbf{p}$} \\
\hline & \multicolumn{2}{|c|}{ Incomplete } & \multicolumn{2}{|c|}{ Complete } & & \\
\hline & $\mathbf{n}$ & $\%$ & $\mathbf{n}$ & $\%$ & & \\
\hline \multicolumn{7}{|l|}{ Maternal education } \\
\hline Low & 99 & 66.0 & 8 & 16.0 & 10.19 & $<0.001$ \\
\hline High & 51 & 34.0 & 42 & 84.0 & & \\
\hline \multicolumn{7}{|l|}{ Information } \\
\hline Received no information & 65 & 43.3 & 3 & 6.0 & 11.98 & $<0.001$ \\
\hline Received information & 85 & 56.7 & 47 & 94.0 & & \\
\hline \multicolumn{7}{|l|}{ Knowledge } \\
\hline Poor & 107 & 71.3 & 6 & 12.0 & 18.25 & $<0.001$ \\
\hline Good & 43 & 28.7 & 44 & 88.0 & & \\
\hline \multicolumn{7}{|l|}{ Perceived benefits } \\
\hline Few & 91 & 60.7 & 4 & 8.0 & 17.74 & $<0.001$ \\
\hline Many & 51 & 34.0 & 42 & 84.0 & & \\
\hline \multicolumn{7}{|l|}{ Perceived barriers } \\
\hline Small & 57 & 38.0 & 36 & 72.0 & 0.24 & $<0.001$ \\
\hline Big & 93 & 62.0 & 14 & 28.0 & & \\
\hline \multicolumn{7}{|l|}{ Intention } \\
\hline Weak & 80 & $53 \cdot 3$ & 3 & 6.0 & 17.91 & $<0.001$ \\
\hline Strong & 70 & 46.7 & 47 & 94.0 & & \\
\hline \multicolumn{7}{|l|}{ Subjective norms } \\
\hline Unsupportive & 78 & 52.0 & 4 & 8.0 & 12.46 & $<0.001$ \\
\hline Supportive & 72 & 48.0 & 46 & 92.0 & & \\
\hline \multicolumn{7}{|l|}{ Attitude } \\
\hline Negative & 70 & 46.7 & 4 & 8.0 & 10.06 & $<0.001$ \\
\hline Positive & 80 & $53 \cdot 3$ & 46 & 92.0 & & \\
\hline
\end{tabular}


Table 4. The multilevel logistic regression analysis of factors influencing Tri Elimination participation

\begin{tabular}{|c|c|c|c|c|}
\hline \multirow{2}{*}{ Independent Variables } & \multirow{2}{*}{$\mathbf{O R}$} & \multicolumn{2}{|c|}{$95 \%$ CI } & \multirow[b]{2}{*}{$\mathbf{p}$} \\
\hline & & Lower Limit & Upper Limit & \\
\hline \multicolumn{5}{|l|}{ Fixed Effect } \\
\hline Education (high) & 24.02 & 1.61 & 359.17 & 0.021 \\
\hline Information (get) & 52.31 & 1.35 & 2021.69 & 0.034 \\
\hline Knowledge (good) & 49.20 & 1.54 & 1574.62 & 0.028 \\
\hline Perceived benefits (many) & 31.26 & 1.28 & 762.77 & 0.035 \\
\hline Perceived barriers (big) & 0.02 & 0.01 & 0.67 & 0.028 \\
\hline Intention (strong) & 17.84 & 1.59 & 199.83 & 0.019 \\
\hline Subjective norm (supportive) & 94.69 & 1.91 & 4683.14 & 0.022 \\
\hline Attitude (positive) & 68.71 & 2.40 & 1967.08 & 0.013 \\
\hline Constanta & 1.33 & 4.72 & 0.01 & 0.005 \\
\hline \multicolumn{5}{|l|}{ Random Effect } \\
\hline \multicolumn{5}{|l|}{ Health center } \\
\hline Var (Constanta) & 0.84 & 0.01 & 123.92 & \\
\hline $\mathrm{n}$ observation $=200$ & & & & \\
\hline n Health center $=21$ & & & & \\
\hline Log-likelihood = - 22.14 & & & & \\
\hline $\mathrm{ICC}=20.42 \%$ & & & & \\
\hline
\end{tabular}

\section{DISCUSSION}

1. The effect of maternal education on completeness of immunization in infants

A study conducted by Balogun et al. (2017) showed that mothers who have higher education were able to complete immunizations for their children because maternal education leads to better health knowledge and behavior.

The results of this study are in line with a study conducted by Forshaw et al. (2017), which stated that the likelihood of complete immunization was greater in children whose mothers received secondary education or higher compared to children whose mothers had no education.

According to the results of Holipah's study, Maharani and Kuroda (2018), children of highly educated mothers were more likely to be fully immunized. A woman with a better educational background was more likely to realize the importance of immunization. Mothers with better educational backgrounds were more likely to accept new and modern ideas, were more confident in making decisions about the health of their families, and were more skilled at obtaining health information.

\section{The effect of information on immu- nization completeness in infants}

Mothers who had received information about immunization from health workers will increase their knowledge, which will lead to a positive attitude towards immunization. Information exposure can produce positive changes and prevent negative changes in health behavior.

This study's results indicate that there was an effect of information on immunization received by mothers on the completeness of immunizations. The effect was positive and statistically significant.

The results of this study are in line with a study conducted by by Lakew et al. (2015), which showed that the complete immunization coverage was related to the information obtained. Children born to mothers who are informed and aware of the immunization programs provided by the government are more likely to receive full immunization. 


\section{The effect of knowledge on comple- teness of immunization in infants}

Maternal knowledge about immunization affects the complete basic immunization status. A mother who has knowledge that immunization can protect her children from disease is likely to give her child complete immunizations (Vonasek et al., 2016).

The results of this study are in line with a study conducted by Putri et al. (2017), which stated that there was an effect of knowledge on complete basic immunization status. Knowledge of a mother's immunization is a factor that influences the mother's attitude in deciding whether or not her child will receive complete basic immunization.

The findings of the multivariate analysis by the study of Ababu et al. (2017) revealed that parents with high knowledge were more likely to immunize their children than parents with low knowledge. This study identified that a good level of knowledge is associated with positive behavior in the use of immunization services.

\section{The effect of perceived benefits on completeness of immunization in infants}

The results of this study support the theory of the Health Belief Model (HBM) developed by Rosenstock. The theory stated that perceived benefits were a determinant component of health behavior, which refers to a person's beliefs about the benefits or benefits that can be felt when preventing a disease (Murti, 2018). The results of this study indicate that there was an effect of perceived benefits on the completeness of immunization. This could be due to exposure to personal factors and social factors about the benefits obtained from immunization so that mothers are sure to immunize their children completely.

This study is in line with a study by Puri et al. (2016), which stated that there was a direct effect between the perceived benefits on the completeness status of immunizations.
Mothers who have the perception that infant immunization is beneficial to have a greater chance of immunizing their babies than mothers who have the perception that immunization in infants is not useful.

\section{The effect of perceived barriers on completeness of immunization in infants}

The results of this study indicated that there was an effect of perceived barriers on completeness of immunization. This study supports the theory of the Health Belief Model (HBM), namely the perceived barriers as a determinant component of health behavior. Perceived barriers can be formed due to exposure to personal factors and other supporting factors that can reduce a mother's confidence in immunizing her child (Murti, 2018). The obstacles faced by mothers to immunize their children completely in this study are generally mothers doubt the safety of vaccines, and parents are afraid of vaccine side effects such as fever.

This study is in line with a study by Puri et al. (2016), which showed that there was an effect of perceived barriers on the completeness of immunization. The study stated that perceived barriers had both direct and negative effects on the completeness of the child's immunization status.

The results of the study conducted by Gupta, Prakash, and Srivastava (2015), also found that the most common reasons for incomplete immunization were family problems (24\%), immunization awareness (20\%), and fear of vaccine side effects (16\%). Other reasons are children are too young for immunization, childhood illness, and parents' distrust in immunization.

\section{The effect of intention on immuniza- tion completeness in infants}

The results of this study indicate that there was an effect of intention on completeness of immunization. This study supports the Theory of Planned Behavior (TPB) proposed 
by Ajzen, which stated that intention is formed from attitudes toward behavior, subjective norms, and perceived behavioral control. These three elements are determinants of the formation of the intention to take any action that will eventually be carried out or not (Azwar, 2013).

The results of a study by Ababu et al. (2017) also showed that parents with high intentions were more likely to vaccinate their children with vaccines than parents with low intentions. The intention is significantly associated with immunization practice, and this finding is consistent with several previous studies conducted in Ethiopia, Brazil, and Nigeria.

According to Theory Planned of Behavior (TPB), the greater the intention, the more likely the behavior will occur. Intention shapes a person's behavior (Murti, 2018).

\section{The effect of subjective norms on the completeness of immunization in infants}

The results of this study indicate that there is an effect of subjective norms through intention on completeness of immunization. This research supports the Theory of Planned Behavior (TPB), which shows that behavior is formed due to the influence of a strong intention from within a person and is determined by one of the concepts, namely subjective norms (Murti, 2018).

This study is in line with Inayati et al. (2017), which shows that there is a significant effect of subjective norms on the use of immunization. Mothers who have supportive subjective norms are more likely to use immunizations for their babies than mothers who do not have subjective norms of support.

\section{The effect of attitudes on the com- pleteness of immunization in the mother's baby}

Attitude is a personal judgment to support or not support the complete immunization action. Attitude can indirectly affect the completeness of immunization. The results of this study indicate that there is an effect of attitude on completeness of immunization.

The results of this study are in line with previous studies that show parents' attitudes towards immunization affect the complete basic immunization status. Mothers with a positive attitude understand that immunization can protect their babies from dangerous diseases. (Inayati et al., 2019).

Mothers who have unpleasant experiences when they immunize their children at health facilities tend to have negative attitudes towards immunization, so they do not return to health facilities to provide further immunizations to their children (Putri et al., 2017).

\section{The effect of contextual health centers on the completeness of immunization}

The Health center prioritizes promotive and preventive efforts. Efforts were made aimed at obtaining a high degree of public health. The community plays a role in health center activities. Immunization is one of the preventive efforts to reduce diseases that can be prevented by immunization (PD3I) (Ministry of Health RI, 2014).

In this study, the health center has a contextual effect with an ICC of $20.42 \%$. Variations incompleteness of immunization in infants as much as $\mathbf{2 0 . 4 2 \%}$ is determined by variables at the health center level. This figure is greater than the standard rule of thumb size of $8-10 \%$, so the contextual influence shown from the multilevel analysis is very important to note.

\section{AUTHOR CONTRIBUTION}

Maharani Ulfah was the main researcher who collected data, formulated data, designed research and conducted questionnaire reliability tests. Supriyadi Hari Respati gave suggestions for discussion of research and 
writing techniques. Bhisma Murti checked the data and analyzed the data.

\section{CONFLICT OF INTEREST}

There was no conflict of interest in this study.

FUNDING AND SPONSORSHIP

This study used the main researcher funds.

\section{ACKNOWLEDGEMENT}

The author would like to express their gratitude to mothers and all health workers at the Karanganyar Health Center who had contributed and were willing to be the study subjects in this research.

\section{REFERENCE}

Ababu Y, Braka F, Teka A, Getachew K, Tadesse T, Michael Y, Birhanu Z, et al. (2017). Supplement article behavioral determinants of immunization service utilization in Ethiopia: a cross-sectional community- based survey. Pan Afr. Med J. 27(2):2. doi: 10. 11604/pamj.supp.2017.27.2.10635

Balogun SA, Yusuf HA, Yusuf KQ, AlShenqiti AM, Balogun MT, Tettey $\mathrm{P}$ (2017). Maternal education and child immunization: the mediating roles of maternal literacy and socioeconomic status. Pan Afr Med J. 26. https://doi. org/10.11604/pamj.2017.26.217.11856

Dinas Kesehatan Kabupaten Karanganyar (2018). Profil kesehatan tahun 2018. Pemerintah Kabupaten Karanganyar

Forshaw J, Gerver SM, Gill M, Cooper E, Manikam L, Ward H (2017). The global effect of maternal education on complete childhood vaccination: a systematic review and meta-analysis. (BMC) Infectious Disease. 17 (1): 1-16. https://doi.org/10.1186/s12879-017-2890-y Inayati R, Rahardjo SS, Murti B (2017). Contextual Effect of the integrated health post on DPT3 immunization
Uptake among Infants in Wonogiri, Central Java. J Matern Child Health. https://doi.org/10.26911/thejmch.2019.04.04.06.

Kementerian Kesehatan Republik Indonesia (2014). Data dasar Puskesmas keadaan Desember 2013. Jakarta: Pusat Data dan Informasi Kementerian Kesehatan RI.

Kementerian Kesehatan Republik Indonesia (2015). Bersama tingkatkan cakupan imunisasi, menjaga anak tetap sehat. Jakarta: Pusat Komunikasi Publik Sekretariat Jenderal Kementerian Kesehatan RI.

Kementerian PPN/Bappenas (2017). Penguatan pelayanan kesehatan dasar di Puskesmas. Jakarta: Direktorat Kesehatan dan Gizi Masyarakat dan Kedeputian Pembangunan Manusia, Masyarakat dan Kebudayaan

Kementerian Kesehatan Republik Indonesia (2018). Berikan anak imunisasi rutin lengkap, ini rinciannya. Jakarta: Pusat Komunikasi Publik Sekretariat Jenderal Kementerian Kesehatan RI

Kementerian Kesehatan Republik Indonesia (2019). PID 2019, tingkatkan cakupan dan mutu imunisasi lengkap. Jakarta: Pusat Komunikasi Publik Sekretariat Jenderal Kemen-terian Kesehatan RI

Kholifah S, Budihastuti UR, Murti B (2019). Factors affecting the use of visual inspection acetic acid test: multilevel analysis on the contextual effect of health center. J Health Promot Behav. 4(1): 111. https://doi. org/10.26911/thejhpb.2019.04.01.01.

Lakew Y, Bekele A, Biadgilign S (2015). Factors influencing full immunization coverage among $12-23$ months of age children in Ethiopia : evidence from the national demographic and health survey in 2011. BMC Public Health. 15 (728):1-8. https://doi.org/10.1186/s12- 
Ulfah et al./ Determinants of Complete Infant Immunization

889-015-2078-6.

Murti B (2018). Teori Promosi dan perilaku kesehatan. Surakarta: Program Studi Ilmu Kesehatan Masyarakat, Program Pascasarjana, Universitas Sebelas Maret

Ntenda PAM, Chuang K-Y, Tiruneh FN, Chuang YC (2017). Analysis of the effects of individual and community level factors on childhood immunization in Malawi. Vaccine. 35(15):19071917. https://doi.org/10.1016/j.vaccine.2017.02.036.

Oleribe O, Kumar V, Awosika-Olumo A, Taylor SD (2017). Individual and socioeconomic factors associated with childhood immunization coverage in Nigeria. Pan Afr Med J. 26:220. https://doi.org/10.11604/pamj.2017.26.220.11453 .

Papadimitriou GN (2017). The "Biopsychosocial Model”: 40 years of applica-tion in Psychiatry. Psychiatriki.28 (2):107110.https://doi.org/10.22365/jpsych.2017.282.107.

Puri YE, Murti B, Dermatoto A (2016). Analysis of the effect of maternal perception on completeness of child immuni- zation status with health belief model. $\mathrm{J}$ Health Promot Behav. 1(3):212-213. https://doi.org/10.26911/thejhpb.2016.01.03.08.

Putri LA, Dewi YLR, Rahardjo SS (2017). Precede-proceed model on the determinants of complete basic immunization status in Bangkalan district, Madura. J Health Promot Behav. 2(4):291-301. https://doi.org/10.26911/thejhpb.2016.02. 04.01.

Satgas Imunisasi PP IDAI (2014). Panduan imunisasi anak mencegah lebih baik daripada mengobati. Edisi 1, cetakan kedua (dengan perubahan). Jakarta: Buku Kompas.

Sunarti (2012). Pro kontra imunisasi bahaya, manfaat dan tips alternatif. Yogyakarta: Hanggar Kreator.

Vonasek BJ, Bajunirwe F, Jacobson LE, Twesigye L, Dahm J, Grant MJ, Sethi AK, et al. (2016). Do maternal knowledge and attitudes towards childhood immunizations in rural Uganda correlate with complete childhood vaccination?. PloS ONE. 11(2):1-16. https://doi.org/10.1371/ journal.pone. 0150131. 